\title{
Intertextualidade e discurso no teatro de Dea Loher
}

\author{
IntertextualitY and discourse in Dea Loher's Theater
}

\section{Júlia Mara Moscardini Miguel}

Universidade Estadual Paulista "Júlio de Mesquita Filho" - UNESP - São Paulo - Brasil

Resumo: O discurso é composto por várias vozes, premissa anunciada desde os estudos de Bakhtin. Os avanços no campo da intertextualidade permitiram uma especificação maior do termo, abrindo espaço para discussão das várias ocorrências do intertexto na literatura. Na obra da dramaturga contemporânea alemã, Dea Loher, há a recorrência do trabalho com o intertexto, sendo que o presente artigo almeja investigar essas manifestações em duas de suas peças, Olgas Raum e Licht. Loher faz uso de citações, referências e alusões, recortando trechos de outros textos e acoplando-os à sua escrita. Esse jogo de recortar e colar é visível também na estética da dramaturga, que recorre a elementos presentes em outras estéticas teatrais e os adapta em sua obra, dando origem a um estilo original. Representante da vertente política no teatro, Loher proporciona ao leitor a possiblidade de reflexão e, nas duas peças em questão, ela o faz através da desconstrução do discurso canônico, mostrando como os discursos são fabricados e como estão ligados à manutenção do poder. Dessa maneira, o intertexto, a estética híbrida e outros recursos estéticos e linguísticos são orquestrados para abrigar essa temática política que chega até o leitor como questionamentos e indagações.

Palavras-chave: Intertextualidade. Dea Loher. Teatro político. Teatro contemporâneo. Memória.

Abstract: Discourse is made of several voices, a premise that was announced since Bakhtin's studies. The advances in the field of intertextuality allowed a wider specification of the term and broaden the discussion of many different occurrence of the intertext in literature. The work of a German contemporary playwright, Dea Loher, brings the recurrence of intertext, and the present paper aims to investigate this manifestation in two of her plays, Olgas Raum and Licht. Loher uses citation, references and allusions, cutting pieces of other texts and pasting them into her writing. This game of cutting and pasting is also visible inside her aesthetic, as she uses elements that are part of other theatrical aesthetics and adapts them in her work, creating an original style. Representing the political side of theater, Loher provides her reader with the possibility of reflecting and, in the considered two plays, she does it through the deconstruction of the canonic discourse, showing how discourses are made and how they are connected to power maintenance. This way, intertext, the hybrid aesthetic and other aesthetical and linguistic resources are organized to receive these political themes that come to the reader as questions and inquires.

Keywords: Metaphor. Intertextuality. Dea Loher. Political theater. Contemporary theater. Memory. 


\section{Introdução}

"Nada se cria. Eu parodio o jogo recortando novos elementos em papel comum que vou pintando sem levar em conta o bom senso." (COMPAGNON, 1996, p.10). Através dessa afirmação, o francês Antoine Compagnon direciona 0 trabalho da citação comparando-a ao jogo infantil de recortar e colar. A práxis literária contemporânea privilegia a citação seja ela direta ou indireta, uma referência ou alusão a outro artista ou outra forma artística. O discurso contemporâneo colabora com a proliferação de várias vozes, entretanto, o diálogo entre textos já fora amplamente discutido desde os estudos de Bakhtin que se concentravam na multiplicidade de vozes que compõe um discurso. Para além da discussão bakhtiniana, o termo intertextualidade vai se moldando entre as várias definições possíveis defendidas por teóricos do discurso.

A também francesa Tiphaine Samoyault aglomera os termos citação, alusão, referência, pastiche, paródia, plágio e colagens como formas de intertextualidade, um conceito espinhoso, dotado de ampla noção definidora que foi capaz de gerar a ambiguidade do termo. O trabalho de Samoyault (2008) é justamente desvendar os entraves que circundam esse fenômeno e sua manifestação nos textos literários pontuando as várias maneiras de retomada textual e sua acomodação em um texto de acolhida. O fenômeno da intertextualidade ocorre de diversos modos e, segundo Samoyault (2008), um texto pode ser retomado de maneira aleatória ou consentida, ou ainda expressar uma tentativa de ratificação ou subversão de um cânone, uma inspiração voluntária, ou uma homenagem.

Expoente da literatura dramática alemã, Dea Loher (1964- ) prioriza uma escrita que combina elementos intertextuais vários. A estética de Loher carrega esse princípio da retomada quando assume em sua forma recursos linguísticos e estilísticos

\footnotetext{
1 É a primeira peça escrita por Loher em 1990, porém, a data de publicação aqui referida é 1994.

2 Peça curta que foi lançada juntamente com outras seis em uma coletânea chamada Magazin des Glücks. As peças são o resultado de um trabalho experimental, fruto da parceria de Loher
}

conferindo à dramaturga originalidade no que diz respeito à aplicação desses elementos advindos de estéticas anteriores. O trabalho estético de Loher aproxima-se da teoria da canadense Linda Hutcheon. A teórica canadense defende a ideia segundo a qual na pós-modernidade a literatura volta seu olhar para o passado, retomando artifícios estéticos e acomodando-os em um novo contexto, o que não significa que se trata de uma mera cópia ou retomada de aspectos preexistentes, mas uma ampliação do prisma estético. O que acontece na pós-modernidade, segundo Hutcheon (1991), é uma apropriação e consequente implosão dos modelos estéticos anteriores, ou seja, eles são empregados de maneira distinta, alegando uma nova intencionalidade amparados por um novo escopo histórico, político, social e cultural.

Nesse âmbito, a obra de Loher é um híbrido estético que acopla elementos de estéticas anteriores, alimentando o objetivo de amplificar o teatro político na contemporaneidade, a fim de proporcionar ao público discussão e reflexão. Além da questão estética que explicita e reverbera a retomada, a dramaturga também faz menção a outros textos e os incorpora à sua escrita e ela o faz de diversas formas, lançando mão de citações, alusões, referências etc. Destacamos duas de suas peças Olgas Raum (1990) e Licht ${ }^{2}$ (2001) nas quais a dramaturga efetua relações intertextuais compondo um discurso permeado de várias vozes. As peças têm em comum o protagonismo feminino personificado em duas figuras públicas de nossa história recente. Ambas as peças refletem sobre a construção do discurso, como o discurso histórico é arquitetado como qualquer outro, além de ser permeado por relações de poder que determinam as escolhas discursivas.

Tais apontamentos convergem para a teoria de Michel Foucault (2014) acerca da "ordem do discurso", ou seja, o teórico acredita que as práticas discursivas são norteadas pelo poder e que os discursos

com o diretor Andreas Kriegenburg. Além da montagem teatral em 2001, a peça recebeu uma versão operística em 2004, dirigida pelo compositor Wolfgang Böhmer. 
disseminados em nossa sociedade são controlados por um sistema dominante detentor deste poder. Assim são criados os discursos da mídia, do capitalismo, da escola e da História, pautados em interesses dominadores que Loher ressalta em suas peças através de uma estética fragmentária, híbrida e original. A dramaturga desconstrói o discurso canônico por meio de recursos estéticos e linguísticos através de uma forma dramatúrgica que prevê cenas curtas, na maioria das vezes intituladas, estruturas sintáticas fragmentárias, flashbacks e o apelo para o intertexto.

\section{Intertextualidade e discurso}

Compagnon (1996) faz um trajeto mostrando o trabalho da citação enquanto uma técnica de colagem, um jogo infantil de recortar e colar. Para o teórico, a citação envolve extrair um texto inicial e acomodá-lo em um texto de acolhida e esse processo de acomodação pode passar por mutilações, subversões e descontinuações, como um trabalho de recorte de jornal que separa as palavras de suas frases originais e as junta em um novo contexto. Além disso, a citação é, segundo Compagnon (1996), "um lugar de reconhecimento, uma marca de leitura" (COMPAGNON, 1996, p.20). Cabe ao leitor um conhecimento prévio para realizar a tarefa de reconhecimento, o que pode acarretar em citação em um texto de acolhida é que Compagnon (1996) atribui à citação a função fática, segundo a definição de Jakobson ${ }^{3}$. Através da citação, o autor faz um convite ao leitor à interrupção, ou ao reconhecimento, trata-se de uma provocação lançada ao interlocutor.

Na obra da dramaturga contemporânea alemã Dea Loher é possível perceber vários momentos de diálogo com o leitor através do trabalho com 0 intertexto. Graduada em Letras Germânicas e Filosofia, Loher lança mão de um rico arsenal literário que coloca em cena para fazer reverberar um teatro político, dialogando com o momento histórico presente e propondo ao seu leitor/espectador uma reflexão acerca da sociedade da qual ele faz parte. Salientamos duas de suas peças Olgas Raum [O canto de Olga] e
Licht [Luz] que apresentam em sua estrutura dramatúrgica o trabalho com a intertextualidade.

Olgas Raum, ou "O canto de Olga", em português, traz ao palco os últimos dias de vida de Olga Benário em uma prisão nazista. A personagem luta para manter-se viva naquele ambiente inóspito enquanto convive e dialoga com suas companheiras de cela Genny e Ana Libre e enfrenta o algoz Filinto Müller. As cenas da peça se alternam em diálogos e monólogos interiores de Olga que conduzem o leitor a um percurso de reconhecimento da personagem, uma figura pública, cuja história é conhecida do grande público, mas cuja vida privada Loher quer fazer conhecer através da ficcionalização dos eventos históricos. A dramaturga utiliza o recurso da memória da protagonista para recontar a história, dessa maneira, os eventos do passado surgem na forma de flashbacks apoiados na narrativa memorialista de Olga. O passado no Partido Comunista e ao lado de Luís Carlos Prestes vai sendo paulatinamente desvelado, mas sempre sob o filtro da memória.

Loher propõe a subversão do discurso histórico quando ela o nivela às demais manifestações discursivas. Essa abordagem é pautada no fato de todo discurso ser filtrado por um enunciador que tem motivações próprias. O historiador, por exemplo, seleciona os fatos e palavras que usa ao materializar os fatos históricos em discurso, isto é, mesmo diante de toda a objetividade discursiva, a noção de "verdade" é relativizada por conta dessa escolha de palavras. Ao abordar uma personagem que faz parte da História oficial e priorizar lembranças e memórias dessa figura por meio de um viés subjetivo, Loher rompe com um padrão discursivo que corrobora com a manutenção de "verdades" absolutas e amplifica o caráter movediço e relativizado de uma história, seja ela "realidade" ou ficção.

Em Olgas Raum, Loher enfatiza a vida privada de Olga Benário, os anseios, dúvidas e angústias dessa mulher, assim como a sua força por ela articulada para enfrentar o seu opositor, o torturador, Filinto Müller. Esse aspecto, permeado pela memória que é lacônica e fragmentária, não é objeto de estudo

\footnotetext{
${ }^{3}$ JAKOBSON, R.. Essais de linguistique générale, 1970, p.217.
} 
e análise da História oficial. Na segunda cena da peça, intitulada "Dueto I: Inventio", Olga relata à colega de cena Genny seu percurso no Partido Comunista, o primeiro encontro com Prestes e a vinda para o Brasil utilizando identidades falsas. Genny é uma jovem de dezessete anos e está assustada, com medo da situação em que se encontra. A jovem fora presa acusada de subversão política e vê em Olga um esteio, uma proteção, além de deixar transparecer admiração por aquela lutadora cuja fama se espalha rapidamente.

Para acalentar o sofrimento de Genny e entretêla do tédio que começa a assolar, Olga passa a narrar suas aventuras do passado. Esta conta à companheira sobre quando morou em Berlim ao lado de Otto Braun e o trabalho dos dois junto ao Partido Comunista, as prisões, as fugas, e a evolução de Olga ao conduzir importantes missões delegadas pelo Partido, como quando foi nomeada para acompanhar Carlos Prestes na viagem de retorno ao Brasil, na qual ambos forjaram identidades para despistar os perseguidores. A narrativa de Olga se detém em fatos históricos como os que aparecem descritos nos livros de Histórias ou nas biografias que relembram os fatos marcantes da vida desta figura. Entretanto, Genny, ao interromper a narrativa de Olga, faz questionamentos e inferências de ordem pessoal e privada, interage com comentários acerca do que diziam as pessoas sobre aquele casal de revolucionários.

Genny fornece uma visão romantizada da suposta vida de Olga e Prestes, como quando se conheceram, sobre amor à primeira vista, bailes e festas. Olga, por sua vez, mantém-se fria em seu narrar, ignorando os comentários da colega de cela. $\mathrm{A}$ cena termina com Genny entoando a canção brasileira Carinhoso, de Pixinguinha e João de Barro. Ela canta: "Ah, se tu soubesses como eu sou tão carinhoso, e o tanto que te quero, e como é sincero o meu amor..." A canção brasileira ilustra a relação de Olga com o Brasil e também a proximidade que a dramaturga Dea Loher tem com o país, já que a peça foi escrita depois de um ano em terras brasileiras. Loher, segundo a pesquisadora Birgit Haas (2006), buscou no Brasil referências para compor a sua dramaturgia. Demonstrando total frustração com o curso de Letras e Filosofia que cursara em Munique, Loher veio ao Brasil em busca de respostas que a universidade não proporcionara.

Ademais, a presença do trecho da canção Carinhoso na peça funciona como as colagens a que Compagnon (1996) se refere. Um texto primeiro que é "recortado" de seu contexto original e "colado" em um texto de acolhida, em um novo contexto. A canção entoada por Genny oferece um contraponto ao discurso frio e enxuto de Olga que se comunica por meio de frases curtas como se fornecesse um relatório breve e objetivo dos acontecimentos passados. Um discurso elíptico revelador de lacunas deixadas na vida dessa mulher que lutou desde os primórdios por uma causa e que sofreu grandes perdas, o companheiro de vida e batalhas, a filha, fruto de sua relação com Prestes, filha que lhe fora tirada dos braços ainda bebê na prisão, além da perda da própria liberdade. Além disso, as frases curtas pronunciadas por Olga sentenciam o ritmo frenético da vida de uma prisioneira constantemente torturada, cujo fim está próximo, ou seja, não há mais tempo para discursos bem elaborados.

O trabalho com o intertexto nesse trecho da peça, portanto, opõe um discurso frio e truncado de quem já passou por agruras diversas com o lirismo e subjetividade da música, através da figura de uma jovem de dezessete anos que apesar de se encontrar na prisão ainda carrega consigo as ilusões da juventude. Olga é o logos, razão, objetividade, enquanto que Genny é o pathos, paixão, subjetividade. Os dois discursos destoam e por isso estabelecem uma relação de complementariedade, a subjetividade de Genny reforça a objetividade de Olga, tornando mais dura a sua descrição. Desde a primeira cena, Olga demonstra essa objetividade, em seu primeiro monólogo ela vai fornecendo sua identidade, a descrição do lugar em que se encontra, seu percurso até chegar ali e sua luta para manter-se viva naquele lugar. A informação é fornecida ao leitor por meio de dados precisos, como nomes próprios, números e frases curtas, objetividade reafirmada na cena seguinte com Genny e suas impressões pessoais que culmina no final da cena com o lirismo da canção. 
A intertextualidade também é um recurso utilizado por Loher em Licht (2001), em português, "Luz". Trata-se de uma peça curta na qual interagem duas personagens, Frau (Senhora) e Shatten (Sombra). A senhora em questão vai fazendo um balanço de sua vida em meio à solidão em que se encontra no momento e a sombra interfere no discurso dessa senhora, trazendo à tona fatos que fazem parte da vida desta. Apesar de não haver nenhuma citação de nome próprio, Birgit Haas (2006) afirma que se trata da história da personagem histórica Hannelore Kohl, esposa do chanceler alemão Helmut Kohl. Hannelore sofria de uma doença dermatológica que lhe causava alergia à luz solar. Os anos de reclusão culminaram com seu suicídio em cinco de julho de 2001. Na peça, Hannelore, identificada apenas como Frau, dialoga com a Sombra, relembrando sua vida e como a reclusão por conta da fotossensibilidade a afastou de tudo, reduzindo-a às sombras de uma vida passada. A senhora comenta sobre como sempre seguia os passos do marido nos eventos oficiais e como o marido foi se afastando, como os filhos foram crescendo e saindo de casa, o cachorro não existe mais, o aquário fora desligado, tudo é solidão em meio à sombra.

Nesse contexto, Loher insere trechos de dois poemas do poeta alemão Rainer Maria Rilke ${ }^{4}$ recitados pela Sombra. Trata-se dos poemas "Ich lebe grad, da das Jahrhundert" (Vivo justamente ao expirar do século) e "Du bist so groß" (Tu és tão grande) ${ }^{5}$, ambos parte de O Livro de horas. Livro primeiro: O livro da vida monástica (1899). Loher cita o primeiro verso de cada poema e separa as duas estrofes com as conjunções und/oder (e/ou). No último verso de cada estrofe, a dramaturga sinaliza com um asterisco e faz a devida citação atribuindo a Rilke a autoria dos versos emprestados. Através dessa citação, Loher separa as vozes da Sombra e de Rilke, indicando um possível diálogo do poeta com a Senhora, do poeta com a Sombra, do poeta com o leitor e do poeta consigo

\footnotetext{
4 Poeta moderno alemão do século XX cuja obra de cunho existencialista reflete sobre o caráter transcendental das relações e do homem. Obra com marcas expressionistas que revelam uma dimensão metafísica e religiosa do autor.

5 Ambas traduções de Paulo Quintana em Rainer Maria Rilke: Poemas, I. Edição portuguesa de 1952.
}

mesmo. A voz de Rilke reverbera nesse momento da peça como a voz de uma autoridade delegada para conjugar a devida importância do sol. Os versos surgem justamente após a Sombra indicar em caixa alta a frase "Ode ao sol".

\section{ODE AN DIE SONNE}

Ich lebe grad, da das Jahrhundert geht.

Man fühlt den Wind von einem großen Blatt, das Gott und du und ich beschrieben hat und das sich hoch in fremden Händen dreht.* [und/oder:]

Du bist so groß, dass ich schon nicht mehr bin,

wenn ich mich nur in deine Nähe stelle.

Du bist so dunkel; meine kleine Helle an deinem Saum hat keinen Sinn.

Dein Wille geht wie eine Welle,

und jeder Tag ertrinkt darin. * (LOHER, 2001, p. 11$)^{6}$.

O segundo poema, mais especificamente, aponta para uma relação entre luz e sombra, uma relação antitética, mas de implicação, ou seja, o sol, que é tão grande, imponente e brilhante, é também escuro porque gera a sombra, sem luz não há sombra, são fenômenos que desempenham uma relação de implicação. Assim acontece com a Senhora, o sol que é para todos sinal vital, promovedor da vida, é para ela uma sentença de morte, já que a exposição aos raios solares ocasiona-lhe graves queimaduras na pele. Para ela, é sempre noite, é sempre escuridão. O jardim que florescia sob a luz radiante do sol agora encontrase sem vida, a piscina está vazia, o cachorro morreu e as crianças se foram. A sombra que se forma em torno dessa Senhora não é apenas a ausência de luz, mas a ausência do marido, dos filhos, da vida ao ar livre e de sua própria liberdade, já que o fato de ser esposa de um importante político acarreta obrigações e compromissos públicos.

Enquanto a Senhora vai se recordando, de forma fragmentária e desconexa, de sua trajetória, a Sombra vai entoando odes ao sol. Após os versos de Rilke, mais uma colagem é aplicada, Loher transplanta para sua peça a canção popular italiana O Sole $\mathrm{Mio}^{7}$

\footnotetext{
6 Vivo justamente ao expirar do século./ Sente-se o vento duma grande folha/ Que Deus e tu e eu escrevemos/ E que se volta, alto, em mãos estranhas./ [E ou:]/ Tu és tão grande que eu já nem existo/ Quando me vou pôr ao pé de ti./ Tu és tão escuro; a minha fraca luz/ Não tem sentido ao pé da tua fímbria./ O teu querer é como uma onda/ Em que vai afogar-se cada dia. (Tradução dos poemas de Paulo Quintela).

${ }^{7}$ Letra de Giovanni Capurro e melodia de Eduardo di Capua.
} 
("Meu sol", em português), na versão oficial em napolitano. A canção aparece com o título, destacado em caixa alta, e separada por colchetes, recurso que isola o intertexto do restante do texto de acolhida de Loher. Mais uma vez, a Sombra empresta sua voz a um enunciado de outrem. A canção exalta o sol e menciona a melancolia trazida pela noite: "Quanno fa notte e 'o sole se ne scenne, me vene quase 'na malincunia; sotto 'a fenesta toia restaria quanno fa notte e 'o sole se ne scenne ${ }^{8}$. O brilho e vivacidade do sol são contrastados com a escuridão e languidez da noite, que se faz presente nas 24 horas do dia da Senhora: Ist immer Nacht/ Die ersten zwölf Stunden/ ist die Nacht bei mir zuhause/ Die zweiten zwölf Stunden/ bin ich draussen in der Nacht" (LOHER, 2001, p.7). ${ }^{9}$

Além de incitar várias odes ao sol, a Sombra toma emprestado outros enunciados que fortalecem a imponência e a vitalidade do astro rei, o que só faz ressaltar o seu malefício à vida daquela Senhora condenada ao isolamento. A Sombra anuncia: "Heute, wieder ein schöner Tag. Sonnig, und das Thermometer steigt am Rhein auf über 240." (LOHER, 2001, p.13). ${ }^{10}$ Um dia claro e ensolarado, propício para atividades externas, significa para a Senhora fechar as cortinas e trancar-se em casa. A Sombra segue enumerando os perigos encontrados até mesmo no interior da casa, como por exemplo os raios de luz da televisão: "Sie sirht keine Nachrichten mehr. Die Strahlen des Fernsehers genügen, die Allergie auszulösen. Bleibt das Radio. Das Telefon. Sie hört die fremden Stimmen durch die abgedunkelten Räume wie Stimmen von Toten aus einem jenseitigen Reich schon." (LOHER, 2001, p. 14) ${ }^{11}$, ou as luzes do aquário: "Schlißlich löscht sie auch das Licht im Aquarium. Nicht einmal das scwache grüngelbe Fluoreszieren ist ihr schmerzlos ertäglich." (LOHER, 2001, p.15) ${ }^{12}$. Tudo que gera luz lembra morte, como as vozes mortuárias ouvidas pela

\footnotetext{
8 Quando desce a noite e o sol deita-se, me pega quase uma melancolia. Ficaria em baixo da sua janela, quando desce a noite e o sol deita-se.

9 É sempre noite/ Nas primeiras doze horas/ a noite está na minha casa/ Nas outras doze horas/ Eu estou lá fora na noite. (Tradução nossa).

10 Hoje, novamente um dia bonito. Ensolarado, e o termômetro sobe no Reno até acima de $24^{\circ}$. (Tradução nossa).
}

Senhora ou como os peixes boiando na superfície quando o aquário é desligado.

A Senhora, juntamente com a Sombra relembram que a vida daquela sempre fora de sombra, frieza e escuridão. Ao leitor é revelado como se davam os eventos sociais a que a esposa do político famoso deveria comparecer. Ele sempre estava cercado de especialistas, conselheiros e consultores. Ela relembra os eternos apertos de mão, gélidos e que pareciam quebrar-Ihe as articulações. A vida em meio a fotógrafos e jornalistas e ela tendo que liderar grupos de voluntariado e associações não-governamentais, posando para fotos com um sorriso truncado e forjado, como o sorriso do gato Risonho. Neste ponto, Loher recorre mais uma vez ao recurso da intertextualidade fazendo alusão ao Edamer Katze, o gato de Lewis Carroll em Alice no País das Maravilhas. Loher usa o termo das Grinsen, ou seja, um tipo de sorriso irônico, além da figura provocadora do Gato Risonho para construir a imagem dessa Senhora ao se deparar com os compromissos políticos oficiais. No caso desta alusão, o leitor é confrontado com informações externas ao texto sendo exigido um conhecimento prévio que ao ser ativado promove uma interpretação mais orientada do que a leitura que não dispõe dos elementos prévios que permitem a identificação do intertexto.

Segundo Michel Foucault em A ordem do discurso (2014), um enunciado é uma proliferação de outros discursos. No caso do discurso literário, o que ocorre é uma retomada de enunciados literários na forma de citações, alusões, referências, ou seja, é uma forma original de mencionar enunciados externos e introduzi-los a um novo discurso que acolhe o excerto e o acomoda em um novo contexto. É isso que Loher faz ao citar Rilke, Lewis Carroll e as canções populares brasileira e italiana. Os enunciados passam a funcionar de outra maneira, contrapondo ou reafirmando seu

\footnotetext{
11 Ela não vê mais notícias. Os raios da televisão bastam para desencadear a alergia. Fica o rádio. O telefone. Ela ouve vozes estranhas através dos quartos escurecidos como vozes de mortos já de um reino do além. (Tradução nossa).

12 Finalmente, ela desliga a luz no aquário. Nem mesmo o fraco verde-amarelo fluorescente é suportável sem dor. (Tradução nossa).
} 
sentido no contexto original. Segundo Compagnon, "a citação é a forma original de todas as práticas do papel, o recortar-colar, e é um jogo de criança." (COMPAGNON, 1996, p.27). As colagens que Loher realiza no âmbito discursivo são também realizadas no âmbito estético. A estética que ela desenvolveu ao longo das várias peças publicadas revela um jogo de colagem que resgata artifícios estéticos já trabalhados em outro contexto histórico, cultural e literário e que são aplicados por Loher no contexto da contemporaneidade para acomodar um novo conteúdo político, isto é, ressaltando as minorias e focando na política das relações humanas.

O teórico e crítico francês Jean-Pierre Sarrazac chama de "escritor-rapsodo" o escritor contemporâneo "que junta o que previamente despedaçou e, no mesmo instante, despedaça o que acabou de unir." (SARRAZAC, 2002, p.37). É isso que Dea Loher faz com a estrutura dramática, junta elementos prévios e os dilui formando uma nova concepção de drama, o que Sarrazac chama de patchwork estético. Nas duas peças citadas anteriormente é possível perceber uma série de recursos estéticos comuns a outras manifestações literárias, como por exemplo o teatro épico de Bertolt Brecht. Em Olgas Raum, Loher recorre aos títulos das cenas que antecipam o seu conteúdo, recurso muito utilizado por Brecht. Já Licht traz uma estrutura muito fragmentária, com frases curtas, desconexas, cuja sintaxe incorpora sentenças incompletas com elementos soltos e ausentes de sentido que muito se assemelha ao Teatro do Absurdo $^{13}$, ou ainda às tendências mais contemporâneas denominadas pós-dramáticas. ${ }^{14}$

No entanto, Loher não pode ser enquadrada em nenhuma dessas estéticas porque seus objetivos e seu escopo histórico e político são diferentes. Segundo Sarrazac (2002),

\footnotetext{
13 Manifestação teatral emergida nos anos 60 cuja definição e sistematização foi feita por Martin Esslin. É característico do Teatro do Absurdo repetições vazias e sem sentido, frases desconexas, jogos de palavras nonsense, personagens que alternam entre a tragédia e a comédia e enredos cíclicos e quase ausentes de ação.

14 Teatro pós-dramático é a denominação para um conjunto de tendências teatrais na contemporaneidade. O alemão HansThies Lehmann em Teatro Pós-dramático (2011) faz um levantamento de todas essas tendências que almejam uma
}

o dramaturgo que quer criar obra nova, alimenta-se generosamente desta memória obscura das formas, coloca-as em tensão, e junta-as numa espécie de mosaico [...] Estas formas, que se chamam apólogo, sátira, parábola, provérbio, alegoria, etc..., desencorajam, pelo seus imprevisíveis reaparecimentos, toda e qualquer tentativa de classificação ou de tipologia. Mas têm, pelo menos, um impulso comum: propor desvios para dar conta do mundo em que vivemos; desenhar as vias oblíquas que permitem à ficção teatral atingir um realismo liberto de todos os condicionalismos dogmáticos. (SARRAZAC, 2002, p.179).

O que Loher faz no teatro pode ser comparado ao que Linda Hutcheon (1947- ) aplica à narrativa. Para ela, "o pós-modernismo é um fenômeno contraditório que usa e abusa, instala e depois subverte, os próprios conceitos que desafia." (HUTCHEON, 1991, p.19). De natureza paradoxal, o pós-modernismo é dotado de ambivalência política e renegocia as fronteiras entre o público e o pessoal, exatamente o que Loher faz em seu drama ao mesclar estas fronteiras fazendo com que os âmbitos público e privado se confundam através de uma estética híbrida, como é o caso das peças já mencionadas nas quais duas personagens históricas, Olga Benário e Hannelore Kohl, são ficcionalizadas. A relação que Loher mantém com o teatro épico e com as demais estéticas com as quais dialoga é a mesma relação de subversão que Hutcheon constata no pós-modernismo.

Essas formas de teoria e prática estéticas inserem e, ao mesmo tempo, subvertem normas predominantes - normas artísticas e ideológicas. Elas são ao mesmo tempo críticas e cúmplices, estão dentro e fora dos discursos dominantes da sociedade. [...] Umas das lições da duplicidade do pós-modernismo é o fato de que não é possível sair daquilo que se está contestando, o fato de que sempre se está envolvido no valor, prefere-se o desafio. (HUTCHEON, 1991, p.279-280).

Portanto, o trabalho que Dea Loher realiza com a intertextualidade no âmbito dos enunciados extraídos de outros discursos é também visível em seu

ruptura com os pilares básicos do drama: ação, diálogo e personagens. As peças consideradas pós-dramáticas têm em comum a ausência de um fio condutor, a predominância de personagens descaracterizados acoplados a uma estrutura fragmentária e desconexa. O suporte midiático também se faz presente bem como um maior envolvimento do público, quebrando de vez com as barreiras entre atores e plateia. 
drama que mescla elementos de estéticas diversas. Loher transforma o texto recortado em material novo que passa a estabelecer uma nova relação com o novo contexto para o qual é deslocado. Com isso, a dramaturga subverte noções já sedimentadas, como por exemplo, a noção de discurso que é desconstruída. A inserção de personagens históricas, os fatos sendo desvelados por intermédio da memória em meio a uma estrutura dramática não convencional são elementos que afirmam o interesse político da arte de Loher.

\section{Subversão de um Cânone}

O político se faz presente na obra de Loher por meio das relações entre as personagens. Para a dramaturga, a concepção de política é encarada de maneira mais ampla, seguindo o pensamento de Foucault que investiga as relações de poder nas interações humanas, descentralizando o poder do controle apenas do Estado. Para Foucault, em Microfísica do poder (1984), este está presente nas relações interpessoais e as personagens de Loher estampam essas relações originando, dessa maneira, o político do teatro loheriano. As relações de dominação e supremacia exprimem poder, como, por exemplo, a relação entre a Senhora e seu esposo político em Licht ou a relação entre Olga e seu torturador, Filinto Müller, ou entre Olga e Genny, a companheira de cela, em Olgas Raum. O poder está concentrado em posse daquele que detém um saber específico e o articula em um discurso convincente.

É considerada política em Licht a relação entre a Senhora e seu esposo, já que este a domina. Ela se coloca sempre a um passo atrás do marido, o acompanha nos compromissos oficiais calada, bem apresentável, maquiada, forjando sorrisos e cumprindo um dever disciplinar. A Senhora sente-se oprimida por essa repetição de comportamento público mantida em nome da profissão e do cargo do marido. O trecho em

\footnotetext{
15 Ela é a esposa de um político. Eles começam na província juntos e ele se mudou para a capital. Ela fica junto dele, ela fica na província, ela fica a dois passos atrás dele. (Tradução nossa). 16 Do termo em alemão Rückenfreihalten, sendo o verbo freihalten proteger, guardar e Rücken, o substantivo costas.

17 Ela está lá para cumprir um dever, cuja necessidade, cujo motivo inevitável alguém fixou há muito tempo no cérebro dela.
}

que a Sombra reitera a submissão da mulher é repetido várias vezes durante a peça: "Sie ist die Frau eines Politikers. Sie haben in der Provinz angefangen, zusammen, und er ist in die Hauptstadt gezogen. Sie bleibt bei inm, sie bleibt in der Provinz, sie bleibt zwei Schritte hinter inm." (LOHER, 2001, p.7) ${ }^{15}$.

A Senhora sente o peso do cargo do marido, a responsabilidade de estar atrás deste homem, apoiando-o, como ela própria diz, é muito importante e significativo "proteger as costas ${ }^{16 "}$ dele. A Sombra interfere na fala da Senhora apontando para a necessidade desse dever disciplinar, fala que se coloca muito próxima à teoria de Foucault em Vigiar e punir (1987). Para Foucault (1987), o poder disciplinar envolve o controle de certas operações de corpo que produzem um homem funcional capaz de manter a sociedade capitalista. É exatamente o que afirma a Sombra:

Sie ist dazu da, eine Pflicht zu erfüllen, derem Notwendigkeit, daren unausweichlichen Grund vor langer Zeit jemand in ihrem Gehirn festgelegt hat. Ein Schaltkreis der Disciplin, die ihren Ursprung in festen bürgerlichen Grundsätzen hat, und an die sie sich krallt wie ein Äffchen an die Brustzitzen seiner Mutter. (LOHER, 2001, p.10) ${ }^{17}$.

A Senhora foi programada para cumprir seu dever, disciplinarmente, de estar atrás do esposo político cumprindo protocolos e isso se tornou uma necessidade para ela, como o seio materno é necessário ao recém-nascido, metáfora que é aplicada na peça aos macaquinhos e à dependência das "tetas" da mãe. Todo um discurso já incutido na mente dessa Senhora a controla e a mantém em "funcionamento" em uma relação de opressão.

Essa relação entre opressores versus oprimidos é ainda mais clara na peça Olga Raum. A relação que Olga mantém com seu torturador Filinto Müller faz oscilar o papel do sujeito da opressão. As três cenas nas quais Olga interage diretamente com Filinto são intituladas Pas de diable, uma clara referência ao passo de balé Pas de deux. No passo clássico, um

Um circuito da disciplina que se originou em princípios sólidos burgueses e a qual ela se agarra como um macaquinho se agarra às tetas da mãe. (Tradução nossa). 
dueto, um casal realiza passos juntos, dançando harmonicamente, repetindo os mesmos passos em uma relação especular de confiança e companheirismo. Já na peça, Haas (2006) afirma que se trata de uma dança da morte com o diabo.

$\mathrm{Na}$ primeira cena, Pas de diable I, Filinto intimida Olga e a ameaça de morte e estupro. Olga, por sua vez, exige ver um médico, afirmando estar grávida de dois meses. A longa cena caminha com as ameaças sórdidas de Müller e a coragem de Olga de responder à altura, não se calando e desferindo xingamentos a seu algoz. Filinto diz que poderia se aproveitar de Olga, mas afirma que vai fazer com que a prisioneira o deseje, mais do que desejava Prestes. Nesse momento, Olga percebe a fraqueza de Filinto e o ataca através das seguintes palavras: "arrivista" e "traidor". Müller era major da Coluna Prestes, lutou ao lado do Cavaleiro da Esperança e, por medo e por não mais acreditar na causa, propôs deserção coletiva da Coluna, sendo expulso sob as acusações de covarde, desertor e indigno. Após a deserção, Müller é nomeado chefe da polícia do Distrito Federal, naquela época localizado no Rio de Janeiro, durante o governo de Getúlio Vargas. Filinto Müller foi um dos responsáveis pela caçada que culminou com a prisão de Prestes e com a deportação de Olga e a entrega desta ao governo nazista.

$\mathrm{Na}$ peça, Loher não fornece esses detalhes históricos sobre Filinto Müller. Olga relembra, em diálogo com o traidor, os fatos mais relevantes da deserção dele. De acordo com os dados históricos, não era Filinto Müller quem torturava Olga na prisão alemã. Loher condensou nessa figura histórica o papel do carrasco maior. Ao tocar no assunto da traição, Filinto vai perdendo a força e a imponência com que torturava Olga no início. Ela usa do discurso para torturá-lo psicologicamente, acusando-o de covarde e traidor. Müller responde às acusações afirmando que bravura nunca lhe faltara, o motivo de sua desistência fora a falta de perspectiva da luta, que ele considerava já perdida. Olga segue acusando o carrasco de ter se vendido por "cem milhões de réis" para capturar Prestes enquanto Filinto, em sua defesa, afirma estar do lado mais forte da batalha, sendo que ao perceber que a Coluna Prestes estava enfraquecida e que o governo juntava forças, ele trocou de lado.

Na cena Pas de diable II, Olga é ainda mais agressiva em sua tortura psicológica, ela instiga Filinto a narrar o que ele faz com os presos no momento da tortura e quando Filinto fornece detalhes da dor submetida aos prisioneiros, Olga acrescenta ao diálogo a família do carrasco indagando sobre a educação dada aos filhos, e seu relacionamento com a esposa. Olga questiona se nos momentos da intimidade do seu lar, ele também aplica os métodos de tortura para conseguir o que deseja. Após um momento de raiva e negação, a supremacia discursiva de Olga leva Filinto a confessar que já torturara a própria esposa. Ao final da cena, a militante revela a seu algoz que tudo fora um sonho, a mente perversa de um torturador cria cenas que não aconteceram de fato. $E$ assim, Olga vence esse embate deixando o torturador mais ferido do que se tivesse sido agredido fisicamente.

O confronto entre Olga e Filinto é um confronto do discurso, enquanto este a ameaça com violência, aquela responde com a violência das palavras, evidenciando o poder do discurso de desestruturar o inimigo. Loher é muito sutil nessa construção. Em nenhum momento da peça ela torna explícita a violência física executada por Filinto, no entanto, ela amplifica as cenas de diálogos, destacando o modo com que Olga refuta o rótulo de vítima e assume a posição de protagonista de sua história armada apenas de seu discurso afiado que é capaz de desarmar o inimigo. As palavras de Olga surtem efeito em Filinto que reage ao ser acusado de traidor e desertor. A dramaturga ilumina o sentimento de ódio e inveja que Filinto sente por Prestes quando este tornou pública a sua deserção, humilhando-o com a expulsão. Müller busca no poder do Estado uma redenção e superação, que Olga faz desabar com as acusações de traição. Loher faz todas as ações se dissiparem em meio à supremacia do poder do discurso.

As obras de Loher refletem a produção do discurso, que não é feita de maneira aleatória. Segundo Foucault (2014),

em toda sociedade a produção do discurso é ao mesmo tempo controlada, selecionada, 
organizada e redistribuída por certo número de procedimentos que têm por função conjurar seus poderes e perigos, dominar seu acontecimento aleatório, esquivar sua pesada e temível materialidade. (FOUCAULT, 2014, p.8-9).

Loher, ao passo que atribui tamanha importância ao discurso de Olga, descontrói e subverte os princípios que regem a retórica clássica. $\mathrm{Na}$ perspectiva de sua dramaturgia, toda e qualquer formação discursiva é fabricada e está passível de formulações diversas, dessa maneira, a dramaturga joga com os enunciados como peças de um quebracabeça, ou um mosaico, construindo e descontruindo os discursos. O romano, orador e mestre de retórica, Quintiliano (35-95), nos doze livros da obra Institutio Oratoria (95), disserta sobre a elaboração do discurso e sublinha os cinco cânones da retórica. Essas cinco dimensões são denominadas como Inventio ou invenção, fase na qual os conteúdos e argumentos que irão compor o discurso são escolhidos; Dispositio ou disposição, ou seja, a organização e estruturação do discurso; Elocutio ou elocução, a expressão e composição linguística do discurso; Memoria, fase da memorização e escrita do texto e Actio ou ação, fase na qual o discurso é declamado.

Em Olgas Raum, Loher retoma os cinco cânones do discurso retórico subvertendo-os de acordo com o desenrolar do enredo. As cinco etapas são, na peça, reduzidas a quatro: Inventio, Accusatio, Negatio, Dementia. A cena intitulada Inventio, já citada anteriormente, apresenta o diálogo de Olga e Genny no qual a primeira relembra os momentos de seu passado ao lado de Prestes e os narra a Genny como forma de acalento e distração. O termo Inventio vem

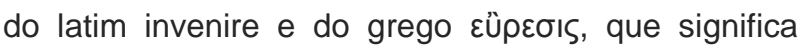
"encontrar". Na retórica de Quintiliano, trata-se do momento em que o orador seleciona os argumentos que serão posteriormente expostos. Na peça, Olga faz uma seleção dos fatos que deseja compartilhar com Genny, fatos resumidos, já conhecidos do público geral, ausente de impressões pessoais.

Já na cena Accusatio, uma nova personagem entra em cena, Ana Libre. Olga e Genny recebem a novata que corresponde, inicialmente, com o silêncio e, em seguida, com agressividade. Ana, armada de muitos xingamentos, acusa Olga de traição pois fora instigada por Filinto a crer que a companheira de Prestes seria uma delatora e estaria contra as demais detentas. Ana acredita que Olga sente-se superior às demais por conta de seu relacionamento com Prestes e pela sua importância na política frente ao Partido Comunista. Mesmo diante das justificativas de Olga, que tenta alertar Ana sobre as maldades de Filinto, esta se mantém irredutível e se isola na cela. Uma cena repleta de acusações por parte de uma personagem que carrega uma visão díspar de Olga Benário: nem vítima, nem heroína, mas uma delatora, imagem construída a partir do discurso convincente do carrasco Müller, almejando desestruturar Olga para que esta se renda e entregue os demais companheiros.

Na cena Negatio, novamente conversam Genny e Olga. Esta assume a função maternal, acariciando Genny para aliviar o medo que a jovem prisioneira sente. O discurso de Olga muda e ela passa a narrar um passado fantasioso, como um conto de fadas que os pais contam para ninar as crianças. A narrativa adquire outro tom e é completamente diferente da narrativa da cena Inventio. Olga dá detalhes da casa onde viveu com Prestes, narra os hábitos e costumes do casal, como uma grande aventura no interior de Minas Gerais. Em contrapartida, Genny passa a desconfiar do enredo adocicado de Olga e a confronta com informações que se aproximam mais da realidade conhecida do grande público. Enquanto Olga descreve uma linda casa de campo com varanda e cercada de cachorros, Genny afirma bruscamente que a casa era pequena, estreita e que mal comportava o casal. Assim segue a descrição de Olga permeada pelo confronto com Genny que em um determinado momento acusa Olga de mentirosa e pede para que ela se cale.

Após um ataque de pânico de Genny alegando sentir medo enquanto a companheira "brinca" de contar histórias, Olga abandona a fantasia e retoma seu discurso truncado, formado por frases curtas e revelando o lado mais traumático de sua experiência com Prestes, as fugas, os esconderijos, a vida a portas trancadas e sem luz. Assim que Olga retoma o tom sombrio e lacônico, Genny volta ao mundo de fantasia imaginando uma linda casa com varanda e os 
cachorros na porta. As duas personagens continuam a dialogar, Olga narrando as mazelas todas enfrentadas por ela e Prestes para não serem descobertos e Genny fantasiando a história da maneira que lhe convém.

Com esse jogo, Loher desconstrói mais uma vez o discurso oficial. Há em nossa sociedade, segundo Foucault (2014), uma necessidade de verdade e essa necessidade opera como um fator coercivo que cria discursos intimamente ligados ao compromisso com o verdadeiro. Para Foucault (2014), nem mesmo as palavras da lei são autorizadas se não por um discurso da verdade. É isso que o discurso histórico busca, se ancorando nas provas materiais para suprir a "vontade de verdade" apontada por Foucault (2014). O discurso histórico, por cumprir com esse compromisso, passa a ser oficialmente aceito e ignora-se que os fatos históricos passam por um filtro no momento em que se tornam discurso. O historiador é movido por uma motivação própria e ao transpor os fatos para o discurso faz uma escolha de palavras que passa a ser a grande verdade aceita e propagada pela sociedade. Loher quebra com essas noções através da história de Olga Benário. Quando esta narra para Genny a história que é concebida como oficial, Genny se sente acalentada e consegue até mesmo divagar sobre o que poderia ter acontecido ao casal de fugitivos. No momento em que Olga adiciona detalhes passionais e subjetivos à sua narrativa, esta se torna menos crível e desestabiliza Genny, que refuta a narrativa. Genny precisa do conforto e da segurança do discurso convencional que tem um compromisso com o verdadeiro, ela exige a verdade que está nos livros de Histórias e que é contada a todos.

A última cena que recebe um título que faz referência ao discurso canônico é Dementia. Nesta cena, Olga e Genny recebem Ana depois desta ter passado por uma sessão de tortura. Ana aparece com os cabelos muito curtos e com as roupas do avesso e os botões trocados. A brava e destemida Ana encontra-se perturbada e desconectada da realidade. Ela chama pelo namorado, Eugênio, e canta uma canção, a mesma que cantou durante a tortura que sofrera, momento no qual Filinto usara o nome do namorado para tirar de Ana informações sobre o paradeiro dos comparsas da prisioneira. Ao presenciarem o estado de Ana, Genny e Olga se compadecem da jovem e juram vingança a Filinto.

A sequência do discurso canônico vai se desfigurando, Loher substitui os nomes de algumas fases propostas por Quintiliano de acordo com os rumos adotados pelo enredo. O discurso se desfaz diante da violência física, por isso a última fase recebe o nome de Dementia. Diante de tanta violência, as palavras tornam-se vãs, enfraquecidas e toda a ordem e controle racionais são perdidos. A altivez e coragem de Ana são desfeitas e transformadas em alienação e demência por conta dos castigos físicos e psicológicos.

Esses efeitos são construídos por Loher através da seriação das cenas, que são justapostas de maneira a mostrar ao leitor o processo de construção e desconstrução do discurso. Olgas Raum é composta de 18 cenas, entre elas, nove monólogos interiores de Olga; dois duetos que recebem numeração (I e II) e subtítulos (Inventio e Negatio); dois trios também numerados e também intitulados (Accusatio e Dementia); um quarteto; três Pas de diable devidamente numerados e uma cena final que recebe o título de Exitus. Os monólogos são intercalados e mostram ao leitor a condição interna da protagonista, seus anseios e medos, sua motivação para continuar viva, ou seja, revelações íntimas que não são encontradas nos discursos oficiais acerca da história de Olga Benário. Nos dois duetos, Olga dialoga com Genny e narra seu passado para consolar a moça. Nos trios, Ana se junta à dupla, primeiramente destemida e intimidadora e, na segunda cena, transtornada após a tortura. O quarteto coloca em cena as três prisioneiras e Filinto Müller no momento em que o carrasco busca Olga para o parto de sua filha. Genny teme pela vida de Olga enquanto Ana se divide entre realidade e delírio. A última cena mostra Olga já na câmara de gás, uma cena poética em que a protagonista se liberta enquanto inspira o gás Ciclone-B. Cada vez mais perto da morte é que Olga se sente viva, livre, como voltando para casa. 
Segundo Flora Süssekind (1998), baseada no ensaio de Edgardo Cozarinsky ${ }^{18}$ sobre o método de escrita borgeano, as séries operam "um sistema de conflitos e elipses, [...] onde o hiato tem tanta importância como os marcos que delimitam a sua extensão." (SÜSSEKIND, 1998, p.138). Na peça de Loher, a seriação das cenas estimula a cooperação do leitor na construção do enredo. Os monólogos são intercalados com as cenas de diálogos, a cada diálogo, a dramaturga incorpora um monólogo na sequência. Com isso, o leitor vislumbra a reação particular da personagem depois de cada cena e essas quebras no enredo promovem a reflexão da personagem que, consequentemente, encadeiam a reflexão do leitor. As passagens de cena deixam elipses no enredo, que o leitor vai deduzindo conforme associa as cenas de diálogos aos monólogos da protagonista.

Um exemplo dessa construção dramatúrgica de Loher está na cena em que aparece a personagem Ana com acusações feitas a Olga. Na cena anterior ao embate, Loher contempla o leitor com as reflexões da protagonista acerca da nova prisioneira, como se Olga apresentasse a jovem recém-chegada e antecipasse a ação da próxima cena. Outro exemplo é o Monólogo IV, quando Olga se previne antes de ser torturada. Ela quer se condicionar a esquecer todos os fatos para não se tornar uma delatora e entregar os nomes e paradeiro dos demais companheiros. A cena sucede 0 embate entre Olga e Ana e, com as palavras desta, a protagonista reflete sobre como não delatar ninguém, e propõe uma tortura ao próprio cérebro para esquecer o passado. Após a cena com Filinto, o monólogo V mostra Olga refletindo sobre o que é a tortura. Para ela, o paradoxo da tortura é ter que esquecer todo o passado para evitar entregar os companheiros a seu algoz, ao passo que é também preciso lembrar o passado para que as lembranças a estimulem a continuar lutando pela vida.

Nesse momento, Loher lança o questionamento que contrapõe realidade e ficção. A necessidade do

\footnotetext{
18 Do cinema, artigo escrito em parceria com Jorge Luís Borges. 19 A tortura é: para cada palavra dita, cada frase dita, encontrar uma palavra não dita, uma frase não dita. É, para cada sílaba pensada, encontra uma outra não pensada, nem mesmo imaginada, que seja quase verdadeira. Verdade e invenção nunca se deixam equilibrar. Para cada história há uma outra. A
}

discurso da verdade é explicitada através da voz de Olga:

Die Folter ist: fur jedes gesprochene Wort, jeden gesprochenen Satz ein unausgesprochenesWort, einen unausgesprochenen Satz zu finden. Já, für jede gedachte Silbe eine andere, nicht gedachte, noch einmal geahnte zu findenm die beinahe die wahre ist. Wahrheit und Erfindung lassen sich einmals ins Gleichgewicht bringen. Für jede Geschichte gibt es eine andere. Die Wahrheit ist die Einbildungskraft. (LOHER, 1990, p.21) ${ }^{19}$

Loher desconstrói mais uma vez o discurso oficial, tido como verdadeiro e a figura de Filinto Müller é trabalhada para ressaltar esse aspecto. Em um exercício metalinguístico, a dramaturga empresta a Olga a reflexão acerca do que é verdadeiro e o que é falso, o que é realidade e o que é ficção. Olga afirma que, na tentativa de criar discursos comprometidos com a verdade e definir homens de verdade, uma falsa verdade surge. O jogo de linguagem de Loher conduz o leitor a perceber o processo de escrita da dramaturga que mistura personagens reais e fictícias, como Filinto, cuja história oficial é uma e a ficcional é outra. Filinto nunca esteve na Alemanha como chefe dos soldados nazistas, sua participação na História se restringe ao serviço militar de apoio ao governo Vargas, ocupação que o permitiu perseguir e capturar Prestes e Olga, o que culminou com a deportação da militante. No entanto, Loher o ficcionaliza dando um rosto a todos os soldados torturadores, propondo a seguinte relação de oposição: homem de verdade versus homem ficcional; discurso histórico versus discurso literário.

A seriação das cenas, sua numeração e o trabalho com os monólogos intercalados são um apoio estrutural na dramaturgia de Loher para conceder esses momentos reflexivos. Olga, através dos monólogos interiores, revela muito de si, antecipando e retomando as cenas, quebrando com a expectativa do leitor e o brindando com uma beleza estética que permite momentos de emoção e reflexão.

verdade é constantemente sabotada pela fantasia, pela força da imaginação. A verdade é a força da imaginação. (Tradução de Marcos Barbosa, autorizada pela editora alemã Verlag der Autoren em 2014). 


\section{Conclusão}

A obra de Loher se apoia em pilares literários canônicos, no entanto, a dramaturga trabalha de maneira a romper com esse cânone não como forma de negação e desprezo, mas na tentativa de adaptar as formas estéticas ao contexto contemporâneo. Para a dramaturga, não faz sentido pensar em teatro sem considerar o âmbito político desta arte e a política encontra terreno fértil na obra loheriana através dos temas atuais e através da maneira com que ela articula as relações entre as personagens. Um teatro focado na política das relações, uma política cujo poder descentraliza o Estado e passa a se realizar nos encontros entre as personagens. O tão almejado poder recai sobre aquele que domina um saber e que é capaz de articular esse saber através de um discurso comprometido com a verdade, já que a sociedade foi moldada para desejar os efeitos de verdade, mesmo que esta seja forjada.

O discurso imprime poder àquele que o profere de forma convincente, alegando serem verdadeiros os enunciados declamados. No entanto, não é possível falar de um discurso uníssono, eles são formados por várias vozes que os compõem e cada voz é dotada de uma intencionalidade, uma motivação diferente. O discurso histórico, por exemplo, é canonizado como um discurso oficial que relata com veracidade os fatos passados. A prova material torna irrefutável o caráter verídico da História. Entretanto, o discurso histórico, mesmo com todo material que prove sua veracidade, passa por um crivo, uma seleção que é feita pelo historiador ao transpor as evidências em discurso. Cada palavra utilizada é uma escolha, assim como o enfoque dado em um determinado fato, tudo é filtrado por aquele que detém o poder de eternizar o passado por meio das palavras. A escola colabora com a proliferação desses discursos prontos e propaga os interesses do Estado na composição do saber do cidadão. Tais fatos convergem para a teoria de Foucault acerca de verdade, disciplina, vigilância e manutenção do poder.

Loher rompe com a supremacia do discurso histórico, bem como com a construção discursiva no geral. Ela opta por trabalhar temas como a solidão, o medo, a busca por liberdade, a submissão da mulher, a doença e as relações familiares, temas muito pertinentes à realidade contemporânea, e ela o faz através da ficcionalização da história oficial de duas figuras públicas, Olga Benário e Hannelore Kohl, universalizando os sentimentos que permearam a existência dessas duas mulheres e que são de caráter universal. A História é diluída em meio a relatos filtrados pela memória dessas mulheres. Nas duas peças, o fio condutor principal dos enredos é a memória, que assume o protagonismo das peças direcionando os rumos da trama.

A memória é lacônica, fragmentária e ausente de cronologia. Loher busca expressar essas características do discurso memorialístico através da estrutura das peças, fazendo uso de frases curtas, cenas curtas, cortes bruscos, incoerência e dubiedade sintáticas. Em Olgas Raum, o foco incide sobre o embate da protagonista que se divide entre o lembrar e o esquecer. Já em Licht, a personagem revive os momentos de sua vida e como ela foi transformada em virtude da doença e do desamparo dos familiares. A memória retoma, em forma de uma sombra, o passado da senhora que vive em isolamento.

O que ambas as peças têm em comum, além do protagonismo da memória, é a ruptura com o discurso histórico oficial. As impressões pessoais, os relatos de uma vida privada são mesclados aos dados oficiais dando origem a um texto que faz arrefecer as fronteiras entre realidade e ficção, através de personagens reais ficcionalizados, amalgamando as esferas do público e do privado.

Esteticamente, Loher emprega uma série de recursos que possibilita esse efeito de subversão e reconstrução do discurso. Ela emprega inúmeros intertextos, dividindo com o leitor a responsabilidade da construção do sentido da peça. As várias vozes que compõem um discurso são desveladas por meio dos intertextos que são acoplados ao texto de Loher. A dramaturga é incisiva ao apontar para a mudança de vozes, pontuando no texto a existência de elementos externos. Loher mostra a construção do discurso justamente ao expor ao leitor a desconstrução de um 
cânone. Os passos que compõem a retórica padrão são desfeitos a partir de cenas seriadas que, intercaladas, antecipam e refletem as demais cenas. Trata-se de uma pluralidade de recursos estéticos e linguísticos utilizados por Dea Loher para reforçar a teoria de que os discursos são construtos sociais e frutos de um poder de dominação que, por sua vez, estabelece um comprometimento com a verdade. A reflexão proposta por Loher é justamente questionar o que é essa verdade, quais os seus impactos na sociedade e como ela é construída e mantida em uma sociedade. As respostas são deixadas em aberto ao leitor ao se deparar com essa arte de cunho político e de grande beleza estética.

\section{Referências}

COMPAGNON, Antoine. O trabalho da citação. Tradução de Cleonice P. B. Mourão. Belo Horizonte: Editora UFMG, 1996. 176 p.

COZARINSKY, Edgardo; BORGES, Jorge Luís. Do cinema. Lisboa: Livros Horizonte, 1986. 117 p.

FOUCAULT, Michel. A ordem do discurso: aula inaugural no Collège de France, pronunciada em 2 de dezembro de 1970. Tradução de Laura Fraga de Almeida Sampaio. São Paulo: Edições Loyola, 2014. 74 p.

Microfísica do poder. Tradução de Roberto Machado. 14. ed. Rio de Janeiro: Graal, 1984. 295 p.

Vigiar e punir. Tradução de Raquel Ramalhete. 27. ed. Petrópolis: Editora Vozes, 1987. $277 \mathrm{p}$.
HAAS, Birgit. Das Theater von Dea Loher: Brecht und (k)ein Ende. Bielefeld: Aisthesis Verlag, 2006. 285 p.

HUTCHEON, Linda. Poética do pós-modernismo. Tradução de Ricardo Cruz. Rio de Janeiro: Imago, 1991. $330 \mathrm{p}$.

JAKOBSON, Roman. Essais de linguistique générale. Paris: Éditions du Seuil. 1970, p.217.

LEHMANN, Hans-Thies. Teatro pós-dramático. Tradução de Pedro Süssekind. 2. ed. São Paulo: Cosac Naify, 2011. 440 p.

LOHER, Dea. Magazin des Glücks. Frankfurt am Main: Verlag der Autoren, 2001. 86 p.

O canto de Olga. Tradução de Marcos Barbosa. Frankfurt am Main: Verlag der Autoren, 2004. Tradução financiada pelo Instituto Goethe. 36 p.

Olgas Raum. Frankfurt am Main: Verlag der Autoren, 1994. 34 p.

QUINTELA, Paulo. Rainer Maria Rilke: Poemas I. Lisboa: Editora Coimbra, 1952, p.122, 134.

QUINTILIANO, Marco Fábio. Intitutio Oratoria. Lisboa: Traduvarius, 2010. $230 \mathrm{p}$.

SAMOYAULT, Tiphaine. A intertextualidade. Tradução de Sandra Nitrini. São Paulo: Aderaldo \& Rothschild, 2008. 160 p.

SARRAZAC, Jean-Pierre. O futuro do drama. Tradução de Alexandra Moreira da Silva. Lisboa: Campo das Letras, 2002. 243 p.

SÜSSEKIND, Flora. A voz e a série. Rio de Janeiro: Sette Letras; Belo Horizonte: Editora UFMG, 1998. 297 p.

\section{COMO CITAR ESSE ARTIGO}

MIGUEL, Júlia Mara Moscardini. Intertextualidade e discurso no teatro de Dea Loher. Signo, Santa Cruz do Sul, v. $41, \quad$ n. 72 , out. 2016. ISSN 1982-2014. Disponível em: <https://online.unisc.br/seer/index.php/signo/article/view/7016>. Acesso em: doi: http ://dx.doi.org/10.17058/signo.v41i72.7016. 